\title{
Thermal Performance of a Domestic Solar Water Heater
}

\author{
Hala K. Saleh \\ Department of Physics \\ College of Science \\ University of Mosul
}

(Received 19/6/2011 ; Accepted 31/10/2011)

\begin{abstract}
An integrated solar water heater was designed and built using local materials and labor. The system consists of $1 \mathrm{~m} \times 1 \mathrm{~m}$ x $0.03 \mathrm{~m}$ rectangular tank. The total cost of the system is 125000 ID. The working principle of the unit is fairly simple. An absorbent surface absorbs solar radiation to heat water.

The performance of the system was tested for four days in April during different atmospheric conditions. In three days, the water temperature reached $60{ }^{\circ} \mathrm{C}$ and higher in partly cloudy, sunny/showers, and sunny/clear sky conditions. However, on a dusty/cloudy day solar radiation was severely reduced keeping the highest water temperature slightly below $30^{\circ} \mathrm{C}$.

The chronic shortage of power supply in Mosul, the abundant sunshine hours in winter and the reasonable cost of the system all serve as good reasons to acquire and install a solar water heater to meet household needs for hot water.
\end{abstract}

Keywords: Domestic, solar radiation, water temperature.

\section{الأداء الحراري لسخلن ماعشهمي محلي الصنغ

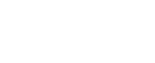

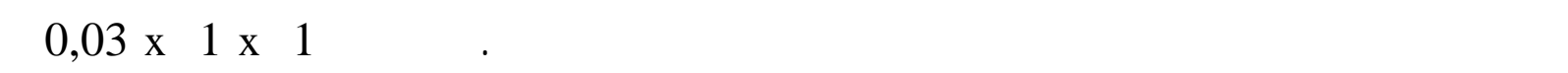

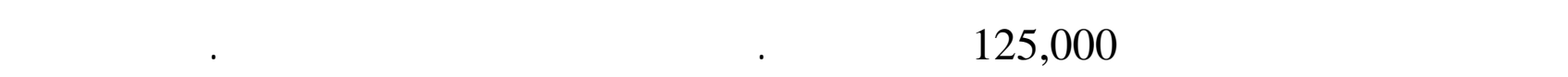
المتصاص يقوم بلمتصاص إثشعاع للثهس لتسخين الماء.

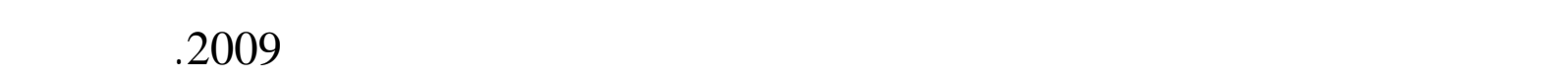

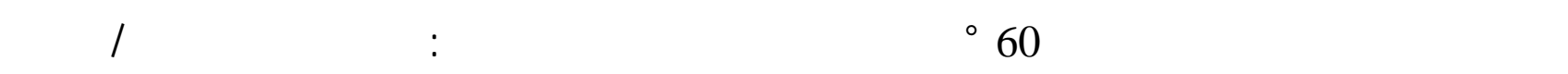

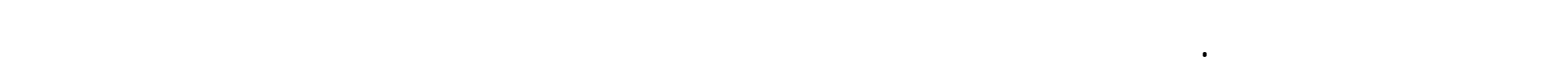
للماء اقل قليلامن 30 نْليزية. إن القص المزمن في تجهيز الطاقة الكهربائية في الموصل، ووفرة الأيلم المشسة في المنتاء وكذلك

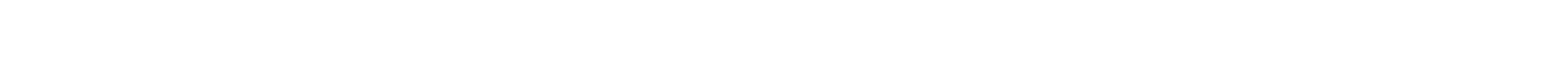
المذزلية للماء الحار. 


\section{INTRODUCTION}

Hot water is a necessity for communities in both developing and developed nations. In developing countries people work hard to meet their hot water needs. Rural households rely on biomass to heat water. However, in developed countries electricity and/or natural gas are commonly used in heating water.

Despite the long winter months in Mosul (Lat. 36.3 N ; Long. $34.15^{\circ} \mathrm{E}$; Elev. $216 \mathrm{~m}$ above MSL), sunshine is abundant. However, electric supply is very limited and intermittent. In fact power supply in Mosul averaged less than 10 hours/day during the last two decades. A good solution to this problem is using solar energy to heat water.

Currently solar water heating technology is in use in different areas of the world including U.S., China, India and the Middle East (Gadgil, 2007). However, the systems used in those countries are sophisticated and very expensive for developing nations to afford.

It is important for developing countries to exploit the solar energy using locallyavailable materials. The basic version is the passive integrated storage-collector solar water heater (also called batch type) consisting of a water tank with a dark absorber (usually a thick coat of black paint) placed in a wooden box with insulation and a sheet of glass on top to create an air gap to trap solar energy.

Basically the idea is simple. Cold water enters at bottom of the tank through an inlet. As the sun heats the absorbent surface, hot water with lower density rises upwards to the top of the tank. If the outlet, at the upper part of the tank, is opened, then hot water flows and cold water passes through the inlet at the bottom.

Generally, two main types of solar water heaters are in use: active and passive systems. An active solar system has an assembly of collectors, storage devices and transformer fluids which convert solar energy into thermal energy (Agbo and Oparaku, 2006). In such system, electric pumps, valves and controllers are used to help water circulation and transfer of fluids through the collectors. Active systems are more expensive than passive systems but are more efficient (Ali et al., 2009).

In passive systems, on the other hand, heat is transferred by convection. Circulation flow rate depends upon the radiation level (Agbo and Oparaku, 2006). Hence, the warmer less dense water rises to the top of the tank. Passive solar water heater systems are reliable, less expensive to maintain and repair, and possibly last longer than active systems (Agbo et al., 2005).

A simple passive solar water heater was proposed by Akuffo and Jackson (1998) in Ghana. The storage capacity of this integrated system was 90 liters. The maximum temperature achieved was $45{ }^{\circ} \mathrm{C}$ by $4: 30 \mathrm{pm}$. Akuffo and Jackson (1998) recommended more insulation to the storage tank to minimize overnight heat loss.

A similar system was introduced by Asif and Muneer (2006). It consisted of a rectangular integrated-collector unit but incorporated fins to enhance thermal performance and structural stability.

Another integrated storage-collector system was introduced by Mohamad (1997). This unit consisted of a tank with a trapezoidal cross section.

Finally, Al-Talib et al., (2009) designed and fabricated an integrated solar water heater in Malaysia. The system is triangular in shape and built by using local materials and labor. It 
was designed to solve the problem of night cooling faced by most types of solar water heaters. Because of better insulating material, very small drops in water temperatures inside the tank took place during the night and warm water could be obtained the next morning.

All the above passive systems had a sheet of glass cover on top maintaining an air gap with the black-painted surface and insulating material for the tank.

\section{DESIGN SELECTION FOR THIS STUDY}

The basic design used in this study is a passive integrated storage-collector unit. The system was built to achieve two objectives. First designing a less expensive solar water heater using local materials and labor. This unit consists of a rectangular galvanized steel tank (1m x $1 \mathrm{~m} \times 0.03 \mathrm{~m})$ with a storage capacity of 30 liters. Five screws were used to support the flat surfaces in order to prevent buckling when filling the tank with water. The sun-facing surface was coated with a thick layer of oil-based black paint. The tank was framed in a wooden box with glass wool insulation to minimize heat loss. A sheet of glass was placed as a cover leaving a $3 \mathrm{~cm}$ gap to create a greenhouse effect (Figs.1,2). The total cost of system, including labor, is 125,000 ID (see table 1 for details).

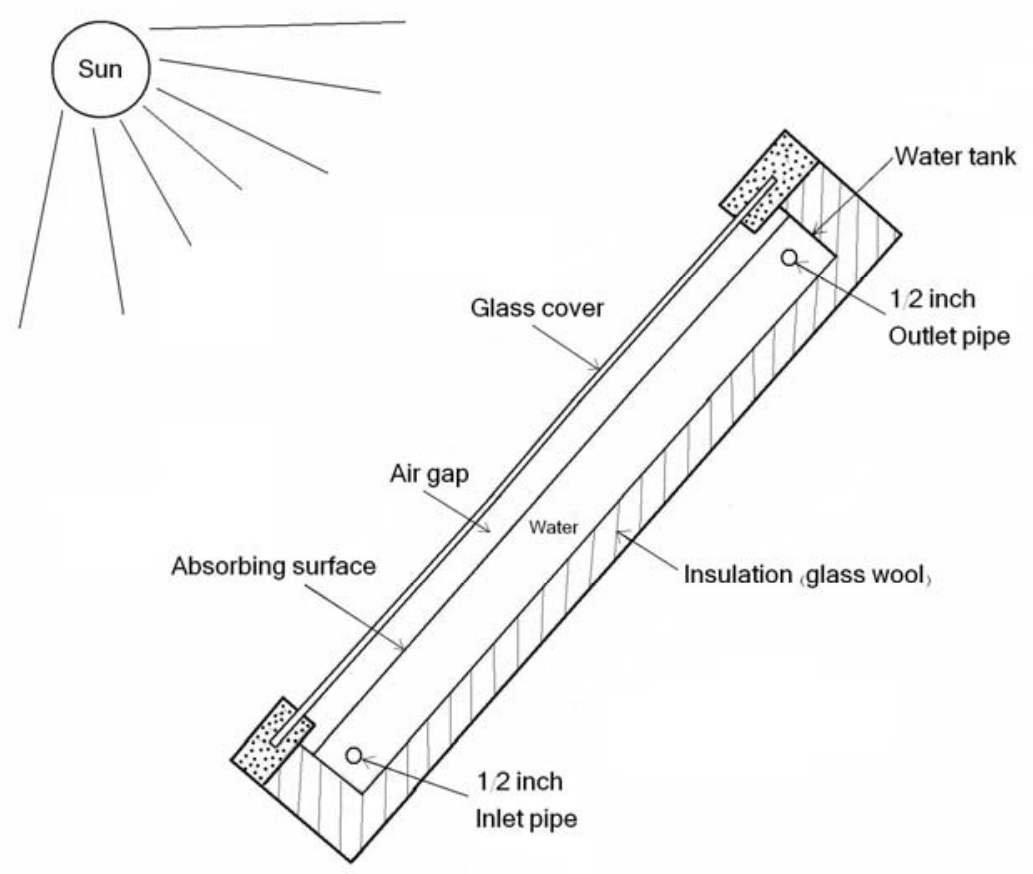

Fig. 1: A schematic diagram for the solar water heater. 


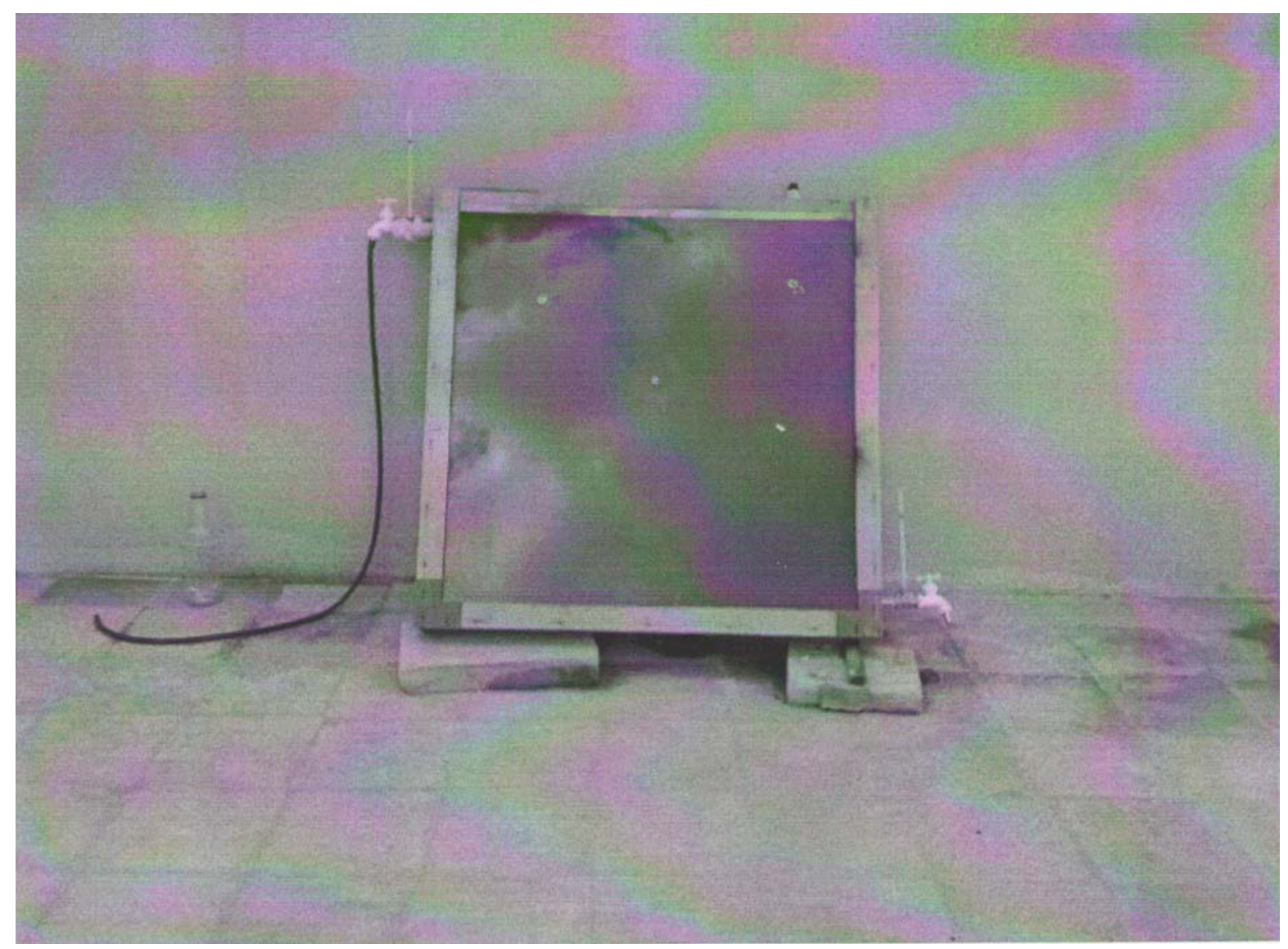

Fig. 2: Integrated solar water heater.

Table 1: Materials used and prices.

\begin{tabular}{|c|c|c|}
\hline Material & Description & Price (ID) \\
\hline Wood & $4 \mathrm{~cm} \times 10 \mathrm{~cm} \times 5 \mathrm{~m}$ & 8000 \\
\hline Plywood & $0.8 \mathrm{~cm}$ x $110 \mathrm{~cm}$ x $110 \mathrm{~cm}$ & 8000 \\
\hline Galvanized steel tank & $0.03 \mathrm{~m} \times 1.0 \mathrm{~m} \times 1.0 \mathrm{~m}$ & 60000 \\
\hline Black paint & $1 / 2$ liter & 2500 \\
\hline Glass wool & $5 \mathrm{~cm}$ x $110 \mathrm{~cm}$ x $110 \mathrm{~cm}$ & 8000 \\
\hline Glass & $4 \mathrm{~mm} \times 1.05 \mathrm{~m} \times 1.05 \mathrm{~m}$ & 8500 \\
\hline
\end{tabular}

A second objective was to test the unit for four days during different weather conditions. The system was tilted about $45^{\circ}$ south-facing angle. Junaidi et al (2007) showed that inclination greatly affects temperature variation along the longitudinal length of the water tank. Two mercury thermometers were placed at the water inlet and outlet to collect temperature recordings. Every morning at 7:30 a.m. during the test of the unit, the tank was first drained and then filled with water by connecting a garden hose to the inlet at the bottom. The tank was always filled to the point when water flowed from the expansion pipe next to the outlet at the top. Then at 8:30 a.m. water temperature was recorded after draining about one liter of water from the outlet into a plastic bottle. Inlet water temperature was also recorded as well. 
This procedure is repeated at one-hour intervals until 5:30 p.m. for each test day (see table 2 for details).

Table 2: Water temperature recordings during four different states of the atmosphere.

\begin{tabular}{|c|c|c|c|c|c|c|c|c|}
\hline \multirow{2}{*}{ 'Temp. ${ }^{\circ} \mathrm{C}$} & \multirow{2}{*}{\multicolumn{2}{|c|}{$\begin{array}{c}\text { Day } 1 \\
07 / 04 / 2009 \\
\text { Cloudy/dusty } \\
\text { High: } 24^{\circ} \mathrm{C} \\
\end{array}$}} & \multirow{2}{*}{\multicolumn{2}{|c|}{$\begin{array}{c}\text { Day } 2 \\
08 / 04 / 2009 \\
\text { Partly cloudy } \\
\text { High: } 29^{\circ} \mathrm{C} \\
\end{array}$}} & \multirow{2}{*}{\multicolumn{2}{|c|}{$\begin{array}{c}\text { Day } 3 \\
\text { 09/04/2009 } \\
\text { Sunny/showers } \\
\text { High: } 22.2^{\circ} \mathrm{C} \\
\end{array}$}} & \multirow{2}{*}{\multicolumn{2}{|c|}{$\begin{array}{c}\text { Day } 4 \\
22 / 04 / 2009 \\
\text { Sunny } \\
\text { High: } 30^{\circ} \mathrm{C} \\
\end{array}$}} \\
\hline & & & & & & & & \\
\hline & Inlet & Outlet & Inlet & Outlet & Inlet & Outlet & Inlet & Outlet \\
\hline $\begin{array}{l}7: 30 \\
\text { a.m. }\end{array}$ & 17 & 17 & 16 & 16 & 16 & 16 & 16 & 16 \\
\hline $\begin{array}{c}\text { 8:30 } \\
\text { a.m. }\end{array}$ & 17 & 17.5 & 17 & 22 & 16 & 19 & 17 & 30 \\
\hline $\begin{array}{c}\text { 9:30 } \\
\text { a.m. }\end{array}$ & 17 & 19 & 17 & 24 & 17 & 32 & 19 & 42 \\
\hline $\begin{array}{c}10: 30 \\
\text { a.m. }\end{array}$ & 17 & 20 & 19 & 37 & 17 & 41 & 19 & 53 \\
\hline $\begin{array}{c}11: 30 \\
\text { a.m. }\end{array}$ & 17 & 21 & 19 & 46 & 19 & 54.5 & 19 & 61 \\
\hline $\begin{array}{c}12: 30 \\
\text { p.m. }\end{array}$ & 18 & 23 & 19 & 52 & 19 & 65 & 20 & 68 \\
\hline $\begin{array}{l}\text { 01:30 } \\
\text { p.m. }\end{array}$ & 18 & 24 & 19 & 60 & 19 & 62 & 20 & 64 \\
\hline $\begin{array}{c}02: 30 \\
\text { p.m. }\end{array}$ & 18 & 25 & 18 & 56 & 19 & 57 & 20 & 57 \\
\hline $\begin{array}{c}\text { 03:30 } \\
\text { p.m. }\end{array}$ & 18 & 27 & 18 & 49 & 19 & 51 & 20 & 52 \\
\hline $\begin{array}{l}\text { 04:30 } \\
\text { p.m. }\end{array}$ & 18 & 28 & 18 & 43.5 & 19 & 46 & 20 & 45 \\
\hline $\begin{array}{c}\text { 05:30 } \\
\text { p.m. }\end{array}$ & 18 & 28 & 18 & 37 & 18 & 40 & 20 & 40 \\
\hline
\end{tabular}

\section{DISCUSSION}

For four days, outlet as well as inlet water temperatures were recorded (Table 2). Those days typically represent weather conditions during April in Mosul city. Fig. (3), a graphical representation of recorded outlet water temperatures clearly shows two distinct patterns of temperature recordings. The first pattern, the lowermost curve, (cloudy/dusty day) shows a slow gradual rise in water temperature. The maximum water temperature achieved was $28^{\circ} \mathrm{C}$ at 5:30 p.m. which was only $10{ }^{\circ} \mathrm{C}$ higher than the inlet water 
temperature. Obviously, dust and cloud severely reduced the amount of solar radiation for that day.

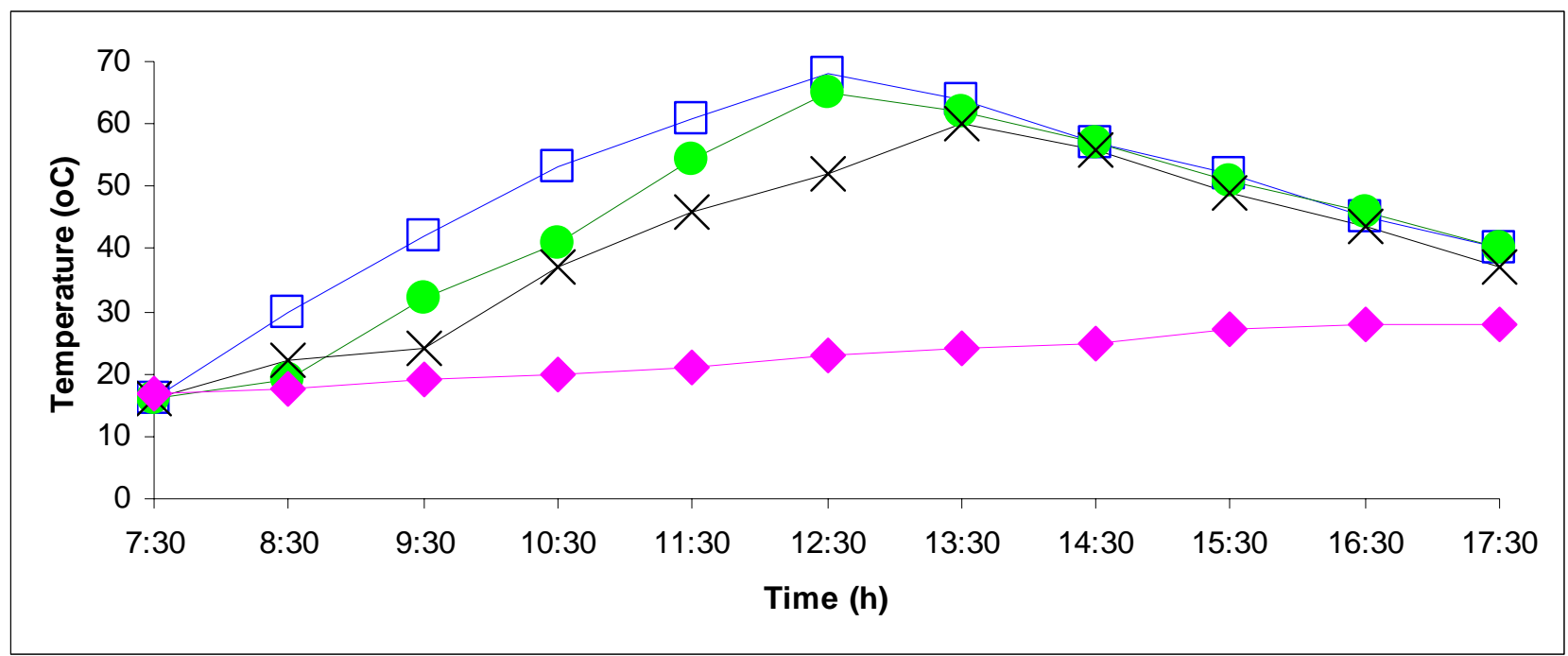

Fig. 3: Comparison of outlet water temperature of the solar water heater during four different weather conditions: cloudy/dusty (solid diamonds), partly cloudy (crosses), sunny/showers (solid circles) and sunny/clear sky (open squares).

The second pattern represented by the upper three curves for the remaining weather conditions, clearly illustrates a peak graph. This pattern shows a rapid rise in water temperatures reaching their highest readings between 12:30-1:30 pm period $\left(60-68{ }^{\circ} \mathrm{C}\right)$. This resulted from of increased solar altitude and reduced optical air mass. It was then followed by a slightly slower drop in water temperatures to around $40{ }^{\circ} \mathrm{C}$ by $5: 30 \mathrm{p} . \mathrm{m}$. The sunny/clear day showed the highest recorded temperature of $68^{\circ} \mathrm{C}$ at $12: 30 \mathrm{p} . \mathrm{m}$.

The best performance of the unit was during sunny clear weather. Also, neither atmospheric nor inlet water temperatures appeared to have an important influence on the outlet water temperatures. In addition, the system proved to function well in cloudy and sunny/rainy days as well.

\section{CONCLUSIONS}

A simple, easy to build solar water heater for household use in Mosul is suggested and tested. The heater can be very helpful in serving family hot water needs. Except for dusty/cloudy conditions water temperature in excess of $60{ }^{\circ} \mathrm{C}$ were obtained. Although the water temperatures produced are less than those produced by imported solar heaters by about $5-10^{\circ} \mathrm{C}$, the cost of the proposed heater is much lower than that of the imported ones. The cost of the suggested heater is only about $\$ 100$ compared with about $\$ 600$ for the imported type. 


\section{ACKNOWLEDGEMENTS}

The author wishes to thank Prof. Dr. A. A. Azooz for suggesting this study, for his kind support and assistance during the setup of the system. His remarks on an earlier draft of this paper are highly appreciated.

\section{REFERENCES}

Agbo, S.N.; Oparaku, O.U., (2006). Positive and future prospects of solar water heating in Nigeria: The Pacific J. Sci. Techn.,.7 (2), 191-198.

Agbo, S.N.; Unachukwu, G.O.; Enibe, S.O.; Okeke, C.E., (2005). Solar water heating for resident university students: Nigeria J. Solar Ener. (15), 85-92.

Akuffo, F.O.; Jackson, E. A., (1998). Simulation studies on a compact solar water heater in the tropics: Solar Wind Techn. (5), 229-237.

Ali, B.; Sopian, K.; Al Ghoul, M.; Othman, M.Y.; Zaharim, A.; Razali, A.M., (2009). Economics of domestic solar hot water heating systems in Malaysia: Eur. J. Sc. Res.,.26 (1), 20-28.

Al-Talib, A..M.; Hamdan, K.; Wahab, M.A., (2009). An economical analysis for stratified integrated solar water heater with triangular shape. J. adv. Sc. Arts,.1 (1), 17-28.

Asif, M.; Muneer, T., (2006). Life cycle assessment of built-in-storage solar water heaters in Pakistan: Build. Serv. Eng. Res. Techn. (27), 63-69.

Gadgil, A., (2007). Domestic solar water heater for developing countries: Ener. Resou. Gr. ER (291) 3- 24.

Junaidi, H.A.; Henderson, D.; Muneer, T.; Grassie, T.; Currie, J. (2007). Study of stratification in a (ICSSWH) Integrated Collector Storage Water Heater: Amer. Inst. Aeron. Astron., (1), 1-7.

Mohamad, A.A.; (1997). Integrated solar collector-storage tank system with thermal diode: Sol. Ener., (61), 211-218. 